\title{
The Affect of Localized Project Managers Factors Which Contribute To Enhance in Minimizing Project Delay of Property Developers in Selangor, Malaysia
}

Tan Tien Shen, Dania Sammani

To Link this Article: http://dx.doi.org/10.6007/IJARBSS/v12-i1/12359

DOI:10.6007/IJARBSS/v12-i1/12359

Received: 14 November 2021, Revised: 18 December 2021, Accepted: 07 January 2022

Published Online: 30 January 2022

In-Text Citation: (Shen \& Sammani, 2022)

To Cite this Article: Shen, T. T., \& Sammani, D. (2022). The Affect of Localized Project Managers Factors Which Contribute To Enhance in Minimizing Project Delay of Property Developers in Selangor, Malaysia. International Journal of Academic Research in Business and Social Sciences, 12(1), 2801-2809.

Copyright: (C) 2022 The Author(s)

Published by Human Resource Management Academic Research Society (www.hrmars.com)

This article is published under the Creative Commons Attribution (CC BY 4.0) license. Anyone may reproduce, distribute, translate and create derivative works of this article (for both commercial and non0-commercial purposes), subject to full attribution to the original publication and authors. The full terms of this license may be seen at: http://creativecommons.org/licences/by/4.0/legalcode

Vol. 12, No. 1, 2022, Pg. $2801-2809$

Full Terms \& Conditions of access and use can be found at http://hrmars.com/index.php/pages/detail/publication-ethics 


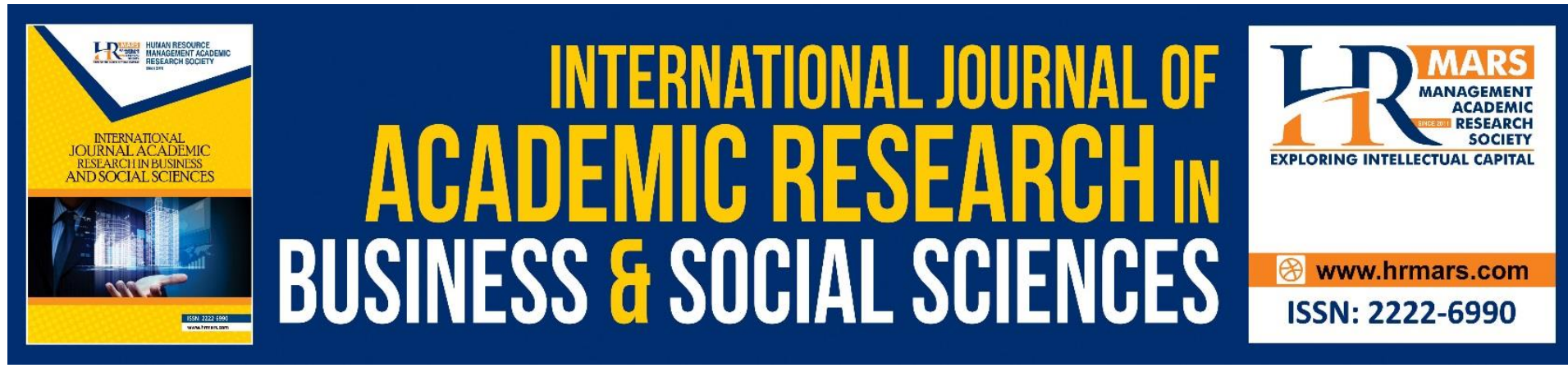

\title{
The Affect of Localized Project Managers Factors Which Contribute To Enhance in Minimizing Project Delay of Property Developers in Selangor, Malaysia
}

\author{
Tan Tien Shen, Dania Sammani \\ Tunku Abdul Rahman University College Malaysia
}

\begin{abstract}
Housing project delays among property development projects still taking place in Malaysia, according to statistics from the Ministry of Housing and Local Government Malaysia, despite the evolution and availability of various project management methods in the literature (AlSehaimi, Koskela, \& Tzortzopoulos, 2013). As a consequence, in project management, an alternative research approach is needed. The aim is to investigate the factors that lead to the reduction of project delays by focusing on a few main factors, such as project manager factors, using a localised alternative research approach. The importance of localizing the analysis of these factors in property developers in Selangor, Malaysia. The study also looked at whether the respondents' demographic characteristics played a role in the disparities found in the project's success factors. Project managers associated with a Property Developer in Selangor, Malaysia, formed the study's target community. A total of 50 people have been chosen to participate in the survey. As a result of studying localized project manager causes of delay factors specifically at Selected Property Development Company in Selangor, Malaysia. A conceptual model that could help improve the reduction of project delays can be develop. This is a more localized alternative research approach, rather than a universal conceptual model.
\end{abstract}

Keywords: Project, Delays, Project Manager, Factors, Property Developer, Selangor, Malaysia, Project Management.

\section{Introduction}

Malaysia is a rapidly developing Asian country whose economy has in the past relied heavily on agriculture, forest ranger service, oil, and other industries. This vision has been shaped as a result of a company contribution that is dependent on the substantial and successful performance of project management operations. In this case, implementation of project management is rapidly changing in Malaysia.

It's now used in almost every project, including government, building, telecommunications, information technology, education, and banking. Project management that is conscious and efficient is vital to an organization's success in increasing productivity. Many Malaysian 
organizations rely on the skills and responsibilities of project managers for protection, performance, and ability.

Despite advancements in project management methods in the construction industry, delay is still occurring at a persistent state. Delay failure can be caused by a variety of factors, including "Delay in material transportation where possible" in the Philippines' "Air Terminal Construction Adventure," as well as machine or transmission failure in the "Xieng Khouang Road Growth." It depends on whether a construction project meets its objectives while staying within budget.

Cost invasion is a mild problem that is almost always associated with construction-related activities. This is becoming more extreme in non-industrialized countries, where these outcomes often surpass some of the usual costs of planned projects.

Despite the fact that project management techniques are commonplace in the construction industry today, previous research has revealed an ineffective track record in managing project projects to solve problems, especially those involving costs and delays. Several ventures in the group that sets cost and time requirements have been unsuccessful.

The key issue is that the project is running behind schedule and will be completed late. Similarly, considering the evolution and availability of numerous project management approaches in the literature, the problem is not fully solved (AlSehaimi et al., 2013).

According to (Portal Rasmi Jabatan Perumahan Negara, 2021), the housing delay in Selangor is the largest, with 10,951 units of housing affected as of October 2021. A total of 8,008 property buyers in the Malaysian state of Selangor have been impacted by the housing development delays.

\begin{tabular}{|c|c|c|c|c|c|c|c|c|c|c|c|c|}
\hline \multirow{2}{*}{ No. } & \multirow{2}{*}{ States } & \multirow{2}{*}{$\begin{array}{c}\text { Licensed } \\
\text { project }\end{array}$} & \multirow{2}{*}{$\begin{array}{c}\begin{array}{c}\text { Project } \\
\text { Not } \\
\text { Started }\end{array} \\
\begin{array}{c}\text { Numbers } \\
\text { of } \\
\text { Projects }\end{array}\end{array}$} & \multicolumn{3}{|c|}{ On Time Project } & \multicolumn{3}{|c|}{ Delayed project } & \multicolumn{3}{|c|}{ Abandoned Project } \\
\hline & & & & $\begin{array}{c}\text { Numbers } \\
\text { of } \\
\text { Projects }\end{array}$ & $\begin{array}{c}\text { Numbers } \\
\text { of } \\
\text { Units }\end{array}$ & $\begin{array}{c}\text { Numbers } \\
\text { of } \\
\text { Purchasers }\end{array}$ & $\begin{array}{c}\begin{array}{c}\text { Numbers } \\
\text { of } \\
\text { Projects }\end{array} \\
\text { prots }\end{array}$ & $\begin{array}{c}\text { Numbers } \\
\text { of } \\
\text { Units }\end{array}$ & $\begin{array}{c}\text { Numbers } \\
\text { Of } \\
\text { Purchasers }\end{array}$ & $\begin{array}{l}\text { Numbers } \\
\text { of } \\
\text { Projects }\end{array}$ & $\begin{array}{c}\text { Numbers } \\
\text { of } \\
\text { Units }\end{array}$ & $\begin{array}{r}\text { Nun } \\
\text { Of } \\
\text { Purs }\end{array}$ \\
\hline 1 & Perlis & 27 & 3 & 19 & 1,174 & 739 & 0 & 0 & 0 & 5 & 235 & \\
\hline 2 & Kedah & 247 & 16 & 197 & 18,195 & 9,920 & 12 & 1,420 & 917 & 22 & 1,774 & \\
\hline 3 & Pulaul Pinang & 163 & 8 & 137 & 34,384 & 14,712 & 3 & 653 & 360 & 15 & 3,062 & \\
\hline 4 & Perak & 474 & 45 & 369 & 37,789 & 18,574 & 11 & 3,352 & 2,242 & 49 & 4,092 & \\
\hline 5 & Selangor & 962 & 43 & 788 & 144,060 & 69,302 & 35 & 10,951 & 8,008 & 96 & 18,300 & \\
\hline 6 & $\begin{array}{l}\text { Wilayah } \\
\text { Persekutuan }\end{array}$ & 245 & 15 & 200 & 132,507 & 79,901 & 3 & 622 & 398 & 27 & 7,618 & \\
\hline 7 & $\begin{array}{l}\text { Negeri } \\
\text { Sembilan }\end{array}$ & 198 & 26 & 150 & 20,064 & 8,733 & 5 & 305 & 69 & 17 & 2,860 & \\
\hline 8 & Melaka & 182 & 15 & 132 & 12,325 & 7,120 & 14 & 2,021 & 1,356 & 21 & 4,087 & \\
\hline 9 & Johor & 495 & 33 & 427 & 77,056 & 27,639 & 1 & 77 & 59 & 34 & 6,754 & \\
\hline 10 & Pahang & 353 & 14 & 312 & 18,254 & 6,164 & 0 & 0 & 0 & 27 & 4,620 & \\
\hline 11 & Terengganu & 99 & 8 & 59 & 4,115 & 3,584 & 3 & 91 & 76 & 29 & 1,873 & \\
\hline 12 & Kelantan & 126 & 9 & 84 & 3,886 & 875 & 0 & 0 & 0 & 33 & 1,748 & \\
\hline & JUMLAH & 3,571 & 235 & 2,874 & 503,809 & 247,263 & 87 & 19,492 & 13,485 & 375 & 57,023 & \\
\hline
\end{tabular}

Table 1. Statistic of Private Sector Housing Project Delay (Portal Rasmi Jabatan Perumahan Negara, 2021) 


\section{Literature Review}

The acquisition of land and the start of construction activities are two major roles played by property developers in Malaysia. Some developers choose an affiliated firm to manage construction, while others use contractors through a competitive bidding process. (Anikeeff \& Sriram, 2008; Anikeeff \& Sriram, 2008) Property developers handle a large portion of this private sector works. Particularly when many companies are opting to lease even their company buildings in order to increase capacity and lower borrowing costs. Because of the perceived risks of acceptance, the developer is the most hesitant member of a creative product's supply chain.

(McCoy et al., 2009)The developer has an enormous obligation to ensure that his/her project is properly accomplished as per sales and purchase agreement, but unfortunately it is not normally the case. Developer shall also responsible for in-house design and planning, project finance, project execution/ management, project definition/formulation, legal agreements, schedule urgency and schedule duration, social elements, policy/social factors and contracting with the assistance of consultants.

Property developers, according to (Ezebilo, 2020), could play a significant role in developing cityscapes and evaluating environmental consequences. Developers want regulatory clarity and operational flexibility, while governments want assurance that developers can adhere to environmental, social, and infrastructure growth requirements (Taylor et al., 2012). Throughout the year, numerous causes of project delays in housing projects have been reported. Organization factors, Financial factors, and Project Manager Factors are among the most significant.

Referring to organization factor, (Dissanayake, 2006) stated organizational is a process of collective consciousness development that occurs when actors collaborate to achieve mutually agreed goals. The interaction of participants, mutual sense-making, and the formation of meaning in the organizational context are defined as the key mechanisms of organizational construction in this sense. More specifically, it supports the notion that organizational rationality, efficacy, and performance, as well as the organizational environment, are all time- and context-bound constructs. As a consequence of all of these factors, the project will be substantially delayed.

Referring to financial factors, since project funding is a major problem for the construction industry, it is the most significant factor that causes delays and cost overruns (Frimpong et al., 2003). Unresolved project funding would have a negative impact on client company and project manager management (Muya et al., 2013), client payment withholding (Booyens et al., 2015), and contractor's unfounded argument (Booyens et al., 2015; Akal, 2019). As a consequence of all of these factors, the project will be substantially delayed.

Referring to project managers, (Alvarenga et al., 2019) stated that a project manager is in charge of ensuring that a project is effective in terms of cost and technical efficiency. He is a project manager who uses his expertise, talents, and experiences to ensure that the project is finished on schedule and on budget. (Sumner et al., 1999) Job assignments can overlap during construction due to a lack of proper planning and control (Arachchige, 2014). Human resource induction and preparation would have a direct negative impact on job effectiveness.(Memon et al., 2014) Failure in making decision and correct action efficiently 
may result the need for change order due to cost increment and the construction will being delayed. (2019, Gonfa) Bad project management would have a direct effect on the subordinates' lives, causing them to lack direction and purpose. As a consequence of all of these factors, the project will be substantially delayed. However, the aim of this study is to find a localised alternative. Therefore we would breakdown the sub-factors for project manager that causes the project delay as follows (Table 2)

Table 2 : 12 sub-factors of Project Manager Causes of Project Delay.

The critical factors, which include organization factors, financial factors, and project manager factors, will be considered independent variable in this analysis, while project success in reducing delays is dependent variable. This is because project success in reducing delays is dependent on the Critical factors.

It shows a direct cause and effect relationship between independent and dependent variable of the study.
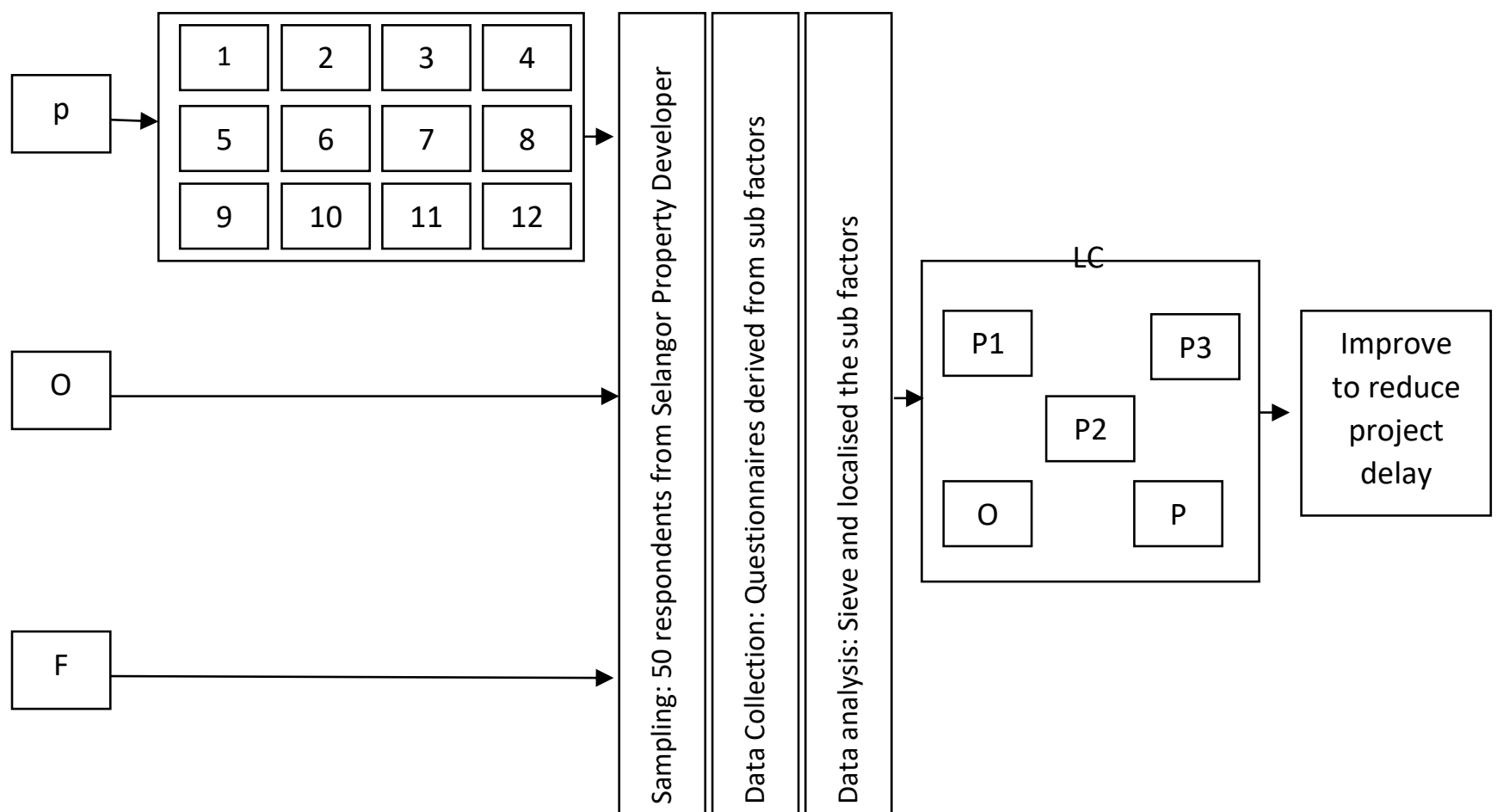

$\mathrm{F}$

Figure 1. Conceptual Model of study between O(Organization factor ), P( Project Manager factor ),F (Financial factors),1,2,3,4,5,6,7,8,9,10,11,12( Project manager subfactor in table 2) and LC ( Localized Caused for Project Delay)

\section{Source : Self proposed}

This study uses a survey tool to collect data on the topic of critical factors to minimise project delay in Selangor, Malaysia. The three factors analysed are (a) organisational factors, (b) financial factors, and (c) project manager factors.

Project managers from organisations in Selangor, Malaysia, make up the target population. The tool's questions are designed to address all of the variables analysed. In the analysis, there are three factors and twelve subfactors that are investigated in the three factors of organisation, financial, and project manager. 
The tool used for this survey is a group of questionnaires that use different scales, including the Likert scale.

The Likert scale asks respondents to respond to a series of proclamations by showing whether they strongly disagree, disagree, neutral, agree, or strongly agree with each statement. Each response is related to a score, and a person's score is determined by adding scores in each link.

The questionnaire is divided into two areas as follows: Part 1: consists of 50 questions identified with the 12 sub- factors in table 3. Area 2: contains questions identified by the respondent's demographics, e.g. B. Gender, ability, long participation times.

A research based on table 2 will be used to collect data on the investigated variables. It will be adapted to the region around Selangor, Malaysia, and will cover additional aspects that relate to the presented questionnaires.

Survey data can be collected manually or sent via email. Then all corresponding answers are collected in a dataset in Microsoft Excel, which can be used in the statistical software package. Statistical Package Social Sciences (SPSS) for Measurable Research. The investigation is performed using descriptive investigation, reliability test and sample t-test. The descriptive research consisted of examining the profiles of the respondents. For example, the survey will determine the gender level of the respondents, the time or knowledge of people in project management, the type of industry.

The 50 respondents were randomly selected from a number of organizations affiliated with project management exercises in property developer in Selangor, Malaysia using the following questionnaire Table 3 which derived from Table 2. 
Table 3 : Questionnaires derived from Table 2.

\begin{tabular}{|l|l|l|l|l|l|l|}
\hline No & $\begin{array}{l}\text { Question of Project Managers } \\
\text { Sub-Factors That Causes } \\
\text { Project Delay }\end{array}$ & $\begin{array}{l}\text { Strongly } \\
\text { disagree }\end{array}$ & Disagree & Neutral & Agree & Strongly Agree \\
\hline 1 & $\begin{array}{l}\text { Poor Project Planning and } \\
\text { Control }\end{array}$ & & & & & \\
\hline 2 & $\begin{array}{l}\text { Lack of induction and training } \\
\text { of human resources }\end{array}$ & & & & & \\
\hline 3 & $\begin{array}{l}\text { Lack of timely Decisions and } \\
\text { Correct Action }\end{array}$ & & & & & \\
\hline 4 & $\begin{array}{l}\text { Poor Leadership on part of } \\
\text { Project Manager }\end{array}$ & & & & & \\
\hline 5 & $\begin{array}{l}\text { Inadequate experience of } \\
\text { staff }\end{array}$ & & & & & \\
\hline 6 & $\begin{array}{l}\text { Lack of effective monitoring } \\
\text { and feedback by project } \\
\text { manager }\end{array}$ & & & & & \\
\hline 7 & $\begin{array}{l}\text { Inaccurate Project Budget } \\
\text { Estimate }\end{array}$ & & & & & \\
\hline 8 & Poor Financial Control & & & & & \\
\hline 9 & Poor Project Implementation \\
\hline 10 & $\begin{array}{l}\text { Delay in Performing } \\
\text { Inspection and Testing }\end{array}$ & & & & & \\
\hline Experiences & & & & & \\
\hline \hline
\end{tabular}

\section{Conclusion}

The study to be conducted in Selangor is to identify the crucial project manager sub-factors for effectively reducing project delays. The role of organisational, financial, and project manager factors in minimising project delays has been also widely documented in the literature.

Using data from 50 respondents in a Property Developer based in Selangor, Malaysia, several new findings will also highlight the value of some important project manager sub-factors that need to be addressed to reduce delay.

Thus, property developers will be able to localise and effectively address the crucial sub-factor to minimise project delay for potential housing projects in Selangor by using the conceptual model in Figure 1.

\section{Acknowledgement}

We would like to thank the people involved in making this article published. Not forget the faculty and university to trust us. Finally, thanks to our family and friends who have supported us all this time. 


\section{Corresponding Author}

Ts. Tan Tien Shen

Department of Quantity Surveying, Faculty of Built Environment, Tunku Abdul Rahman University College

Email: Jtienshen77@gmail.com

\section{References}

\section{Journal Article}

AlSehaimi, A., Koskela, L., \& Tzortzopoulos, P. (2013). Need for Alternative Research Approaches in Construction Management: Case of Delay Studies. Journal of Management in Engineering, 29(4), 407-413. https://doi.org/10.1061/(asce)me.19435479.0000148

Alvarenga, J. C., Branco, R. R., Guedes, A. L. A., Soares, C. A. P., \& Silva, W. da S. (2019). The project manager core competencies to project success. International Journal of Managing Projects in Business, 13(2), 277-292. https://doi.org/10.1108/IJMPB-12-20180274

Anikeeff, M. A., \& Sriram, V. (2008). Construction management strategy and developer performance. Engineering, Construction and Architectural Management, 15(6), 504513. https://doi.org/10.1108/09699980810916951

Arachchige, B. (2014). Absence of Induction and its Impact on the Organization. The IUP Journal of Management Research, (2), 7-16.

Booyens, D., Farrell, S., Garnett, D., \& Perreira, R. (2015). The effect of client interference on construction projects in South Africa. Proceedings of The 3rd Virtual Multidisciplinary Conference, 3(December), 271-278. https://doi.org/10.18638/quaesti.2015.3.1.222

El-Kholy, A. M., \& Akal, A. Y. (2019). Determining the stationary financial cause of contracting firms failure. International Journal of Construction Management, 0(0), 1-16. https://doi.org/10.1080/15623599.2019.1584836

Ezebilo, E. E. (2020). Evaluation of construction, marketing and management in housing delivery by a private developer: evidence from Papua New Guinea. Journal of Housing and the Built Environment, (0123456789). https://doi.org/10.1007/s10901-020-09730-y

Frimpong, Y., Oluwoye, J., \& Crawford, L. (2003). Causes of delay and cost overruns in construction of groundwater projects in a developing countries; Ghana as a case study. International Journal of Project Management, 21(5), 321-326.

https://doi.org/10.1016/S0263-7863(02)00055-8

Gonfa, B. D. (2019). Effects of Poor Leadership Skill in Organization : Evidences. Arabian Journal of Business and Review, 9(2), 1-5.

McCoy, A. P., Thabet, W., \& Badinelli, R. (2009). Understanding the role of developer/builders in the concurrent commercialization of product innovation. European Journal of Innovation Management, 12(1), 102-128. https://doi.org/10.1108/14601060910928193

Memon, A. H., Rahman, I. A., \& Hasan, M. F. A. (2014). Significant causes and effects of variation orders in construction projects. Research Journal of Applied Sciences, Engineering and Technology, 7(21), 4494-4502. https://doi.org/10.19026/rjaset.7.826

Muya, M., Kaliba, C., Sichombo, B., \& Shakantu, W. (2013). Cost escalation, schedule overruns and quality shortfalls on construction projects: The case of Zambia. International Journal of Construction Management, 13(1), 53-68.

https://doi.org/10.1080/15623599.2013.10773205 
Sumner, M. (1999). Critical success factors in enterprise wide information management systems projects. Proceedings of the ACM SIGCPR Conference, 297-303. https://doi.org/10.1145/299513.299722

Taylor, B. M., Harman, B. P., Heyenga, S., \& McAllister, R. R. J. (2012). Property Developers and Urban Adaptation: Conceptual and Empirical Perspectives on Governance. Urban Policy and Research, 30(1), 5-24. https://doi.org/10.1080/08111146.2011.639178

\section{Online Articles}

Portal Rasmi Jabatan Perumahan Negara. Ehome.kpkt.gov.my. (2021). Retrieved 14 March 2021, from https://ehome.kpkt.gov.my/index.php/pages/view/79. 